Vol 11, Issue 6, 2018

\title{
A NOVEL REVERSED-PHASE HIGH-PERFORMANCE LIQUID CHROMATOGRAPHY METHOD FOR SIMULTANEOUS ESTIMATION OF DROTAVERINE HYDROCHLORIDE, ETHAMSYLATE, AND TRANEXAMIC ACID IN TABLET DOSAGE FORM
}

\author{
SWATI SAHANI, VANDANA JAIN* \\ Department of Quality Assurance, Oriental College of Pharmacy, Navi Mumbai, Maharashtra, India. Email: vandana.jain@ocp.edu.in \\ Received: 16 January 2017, Revised and Accepted: 17 February 2018
}

\section{ABSTRACT}

Objective: The objective of this study was to develop and validate a simple, rapid, accurate, and precise reversed-phase high-performance liquid chromatographic method (RP-HPLC) for simultaneous estimation of drotaverine hydrochloride, ethamsylate, and tranexamic acid in tablet dosage form.

Methods: The chromatographic separation was achieved using stationary phase C18 shim-pack GIST (150 mm $\times 4.6 \mathrm{~mm}, 5 \mu$ ) column and mobile phase consists of methanol:potassium dihydrogen phosphate buffer ( $\mathrm{pH} 3.0$ adjusted using orthophosphoric acid) in a ratio of 30:70 v/v, with a flow rate of $1 \mathrm{ml} / \mathrm{min}$ and ultraviolet detection at $220 \mathrm{~nm}$.

Results: The retention time of tranexamic acid, ethamsylate, and drotaverine hydrochloride was found to be 3.6, 4.0, and 5.0 min, respectively. The developed method was validated for linearity, accuracy, precision, and robustness according to the international conference on harmonization guidelines. The method was found to be linear over the tested concentration range of $48-112 \mu \mathrm{g} / \mathrm{ml}$ for drotaverine hydrochloride, $150-350 \mu \mathrm{g} / \mathrm{ml}$ for ethamsylate, and 150-350 $\mathrm{\mu g} / \mathrm{ml}$ for tranexamic acid. Mean percentage recoveries were found to be 99.59 for drotaverine hydrochloride, 99.27 for ethamsylate, and 99.71 for tranexamic acid. The correlation coefficient for all components was found to be more than 0.999 .

Conclusion: A novel RP-HPLC method was developed and validated for simultaneous for the estimation of drotaverine hydrochloride, ethamsylate, and tranexamic acid to their commercially available tablet dosage form.

Keywords: Drotaverine hydrochloride, Ethamsylate, Tranexamic acid, Reversed-phase high-performance liquid chromatography, International conference on harmonization, Validation.

(c) 2018 The Authors. Published by Innovare Academic Sciences Pvt Ltd. This is an open access article under the CC BY license (http://creativecommons. org/licenses/by/4. 0/) DOI: http://dx.doi.org/10.22159/ajpcr.2018.v11i6.24777

\section{INTRODUCTION}

Drotaverine is chemically 1,2,3,4-tetrahydro-6,7-diethoxy-1-((3,4diethoxyphenyl) methylene)-isoquinoline hydrochloride (Fig. 1a) and its molecular formula is $\mathrm{C}_{24} \mathrm{H}_{31} \mathrm{NO} \cdot \mathrm{HCl}[1,2]$. It belongs to the class of antispasmodic agent act by inhibiting phosphodiesterase 4 and has no anticholinergic effects. It is specifically used for smooth muscle spasm and pain. Chemically, ethamsylate is N-ethylamine 2,5 dihydroxy benzene sulfonate (Fig. 1b) andits molecular formula is $\mathrm{C}_{10} \mathrm{H}_{17} \mathrm{NO}_{5} \mathrm{~S}$ [3]. It has been used as hemostatic compound that blocks prostacyclin synthetase, an enzyme that converts arachidonic acid to prostacyclin and therefore increases platelet aggregation and platelet adhesiveness. It is used for the prevention and treatment of capillary hemorrhage and postpartum hemorrhage $[4,5]$. Ethamsylate is officially present in British Pharmacopoeia [6].

Tranexamic acid is chemically trans-4-aminomethylcyclohexaecarboxylic acid (Fig. 1c) and its molecular formula is $\mathrm{C}_{8} \mathrm{H}_{15} \mathrm{NO}_{2}$ [3]. It competitively inhibits the activation of plasminogen, thereby reducing conversion of plasminogen to plasmin (fibrinolysin), an enzyme that degrades fibrin clots, fibrinogen, and other plasma proteins including the procoagulant factors $\mathrm{V}$ and VIII. It is used for controlling abnormal bleeding during mensuration and pregnancy $[4,5]$. Tranexamic acid is officially present in British Pharmacopoeia [6]. The combination of drotaverine hydrochloride, ethamsylate, and tranexamic acid is used in the treatment of menstrual pain, bleeding, and abdominal pain.

Literature survey reveals that spectrophotometric [7-9], highperformance thin-layer chromatography (HPTLC) [10] and reverse- phase HPLC (RP-HPLC) [11,12] based methods have been reported for analysis of these drugs alone and in combination with other drugs. However, there is no reported method for simultaneous estimation of all three drugs in pharmaceutical dosage form. Therefore, an attempt has been made to develop a novel, rapid, and sensitive method for simultaneous determination of drotaverine hydrochloride, ethamsylate, and tranexamic acid in marketed formulation and validate the developed method in accordance with the international conference on harmonization (ICH) guidelines and also to perform the force degradation studies using developed method. This novel validated method has applicability in industry and academia for routine quality control testing [13].

\section{METHODS}

\section{Chemical and reagents}

Drotaverine hydrochloride, ethamsylate, and tranexamic acid reference standards were purchased from Yarrow Chem Pvt, Ltd., India. All other chemicals and reagents used were of analytical grade. Ethamax-Td (Convina Research Laboratory, India) tablet formulation containing drotaverine hydrochloride $80 \mathrm{mg}$, ethamsylate $250 \mathrm{mg}$, and tranexamic acid $250 \mathrm{mg}$ was procured from local market.

\section{Instrumentation}

A RP-HPLC (Shimadzu) LC-2030 model equipped with laboratory solution software, an autosampler and ultraviolet (UV)-visible detector was used. The analysis was carried out on C18 shim-pack GIST $(150 \mathrm{~mm} \times 4.6 \mathrm{~mm} 5 \mu)$ column used as stationary phase. A freshly prepared mobile phase consisting of methanol:potassium dihydrogen phosphate buffer (pH 3.0 adjusted using orthophosphoric acid) in a 
ratio of $30: 70 \mathrm{v} / \mathrm{v}$ was used. The mobile phase was filtered by $0.45 \mu \mathrm{m}$ membrane filter and sonicated before use. The flow rate of mobile phase was $1 \mathrm{ml} / \mathrm{min}$, column temperature was maintained at $25^{\circ} \mathrm{C}$, detection was carried out at $220 \mathrm{~nm}$, and the runtime was around $10 \mathrm{~min}$.

\section{Selection of wavelength}

A UV spectrum of drotaverine hydrochloride, ethamsylate, and tranexamic acid in water was noted by scanning the solution in the range of 200-400 nm. Drotaverine hydrochloride, ethamsylate, and tranexamic acid were showing significant absorption at $220 \mathrm{~nm}$. Thus, $220 \mathrm{~nm}$ was selected as wavelength for analysis.

\section{Preparation of standard stock solution}

The standard stock solutions $100 \mathrm{mg} / \mathrm{ml}$ each of drotaverine hydrochloride, ethamsylate, and tranexamic acid were prepared. Further, solution with concentration of $80 \mathrm{mg}$ drotaverine hydrochloride, $250 \mathrm{mg}$ ethamsylate, and $250 \mathrm{mg}$ tranexamic acid was prepared by diluting stock solution with mobile phase.

\section{Preparation of sample solution}

A total of 10 tablets were weighed, their mean weight was determined and crushed in mortar. An amount of powder weight equivalent to $80 \mathrm{mg}$ drotaverine hydrochloride, $250 \mathrm{mg}$ ethamsylate, and $250 \mathrm{mg}$ tranexamic acid was taken and transfer to $100 \mathrm{ml}$ volumetric flask. The powder obtained was dissolved in mobile phase and sonicated for 20 min for complete extraction. The solution was made up to the volume with mobile phase. The solution was filtered through membrane filter. The stock solution was further diluted with mobile phase to get concentration of $80 \mu \mathrm{g} / \mathrm{ml}$ drotaverine hydrochloride, $250 \mu \mathrm{g} / \mathrm{ml}$ ethamsylate, and $250 \mu \mathrm{g} / \mathrm{ml}$ tranexamic acid.

\section{Method validation}

System suitability

System suitability tests are a fundamental part of liquid chromatographic method. It ensures that system is working correctly. System suitability parameters such as number of theoretical plates, retention time, and tailing factor were evaluated. This was performed by injecting mixture of standard in six replicates.

\section{Linearity}

The linearity of the proposed method was determined by quantitative dilution of the standard solution of drotaverine hydrochloride, ethamsylate, and tranexamic acid to obtain solution in concentration range of $48-112 \mu \mathrm{g} / \mathrm{ml}, \quad 150-350 \mu \mathrm{g} / \mathrm{ml}$, and $150-350 \mu \mathrm{g} / \mathrm{ml}$, respectively. A graph of peak area versus concentration in $\mu \mathrm{g} / \mathrm{ml}$ was plotted for all three drugs in triplicate. The slope, intercept, and correlation coefficient of regression line were determined.

\section{Limit of detection (LOD) and limit of quantitation (LOQ)}

The LOD and LOQ represent the concentration of analyte that would yield to signal-to-noise ratio of 3 for LOD and 10 for LOQ. LOD and LOQ were calculated using following formula,

\section{$\mathrm{LOD}=3.3 \delta / \mathrm{S}$}

\section{$\operatorname{LOQ} \delta / \mathrm{S}$}

where, $\delta=$ standard deviation of response (peak area) and $\mathrm{S}=$ average of slope of the calibration curve.

\section{Method precision}

The method precision of the proposed method was determined by injecting six replicates of sample and standard on the same day to ensure that the analytical method is repeatable.

\section{System precision}

The system precision is checked by injecting six replicates of standard solution to ensure that the analytical system is working properly.

\section{Accuracy}

The accuracy of this method was determined by calculating recovery of drotaverine hydrochloride, ethamsylate, and tranexamic acid by the standard addition method. Known amount of each drug standard solution was added to the preanalyzed sample corresponding to $80 \%$, $100 \%$, and $120 \%$ of the label claim. At each level, three determinations were performed.

\section{Robustness}

Robustness is the measure of method capacity to remain unaffected by small, but deliberate variations in method parameters such as mobile phase flow rate $( \pm 0.2 \mathrm{ml} / \mathrm{min})$, wavelength $\mathrm{nm}( \pm 1 \mathrm{~nm})$, and column oven temperature $\left( \pm 1^{\circ} \mathrm{C}\right)$.

\section{RESULTS AND DISCUSSION}

\section{Optimized chromatographic conditions}

The developed method was finally optimized with following chromatographic conditions. Mobile phase consisting of methanol:potassium dihydrogen phosphate buffer (pH 3.0 adjusted using orthophosphoric acid) in a ratio of 30:70 v/v. The analysis was carried out in an isocratic elution mode using a flow rate of $1.0 \mathrm{ml} / \mathrm{min}$, at $25^{\circ} \mathrm{C}$ and detection was carried out at $220 \mathrm{~nm}$. The retention time of tranexamic acid, ethamsylate, and drotaverine hydrochloride was found to be 3.6, 4.0, and 5.0 min, respectively, as shown in Fig. 2

\section{System suitability}

The system suitability was performed by injecting mixed standard solution containing $80 \mu \mathrm{g} / \mathrm{ml}$ of drotaverine hydrochloride, $250 \mu \mathrm{g} / \mathrm{ml}$ of ethamsylate, and $250 \mu \mathrm{g} / \mathrm{ml}$ of tranexamic acid in six replicates. The acceptance criteria for evaluating system suitability are percent relative standard deviation ( $\% \mathrm{RSD}$ ) $<2$, tailing factor $<2$, and theoretical plate $>1500$. The result indicates that the system suitability parameters are within the acceptable limits, hence, ideal for the chromatographed sample. The results are summarized in Table 1.

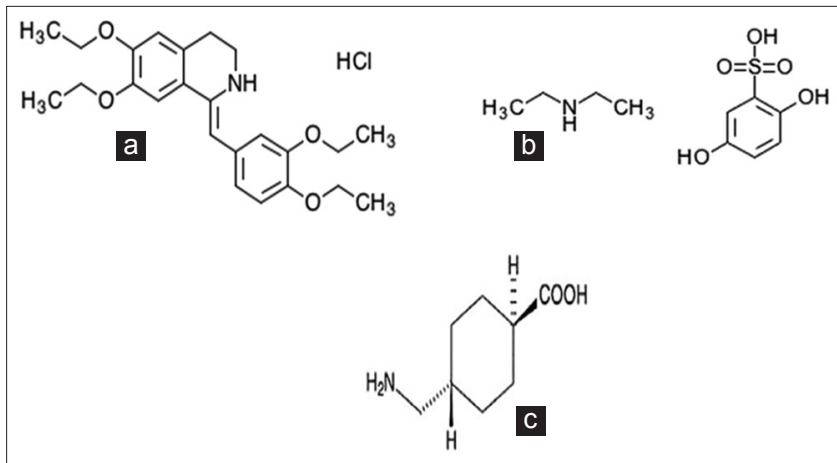

Fig. 1: Chemical structures of (a) drotaverine hydrochloride, (b) ethamsylate, and (c) tranexamic acid

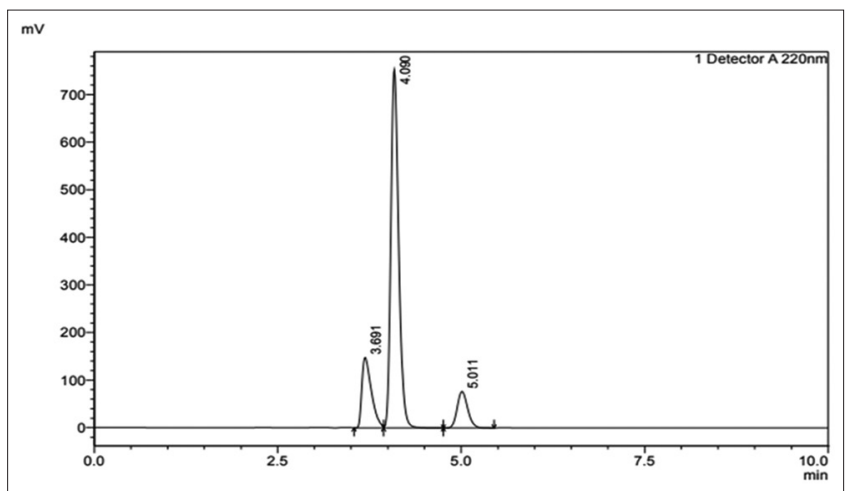

Fig. 2: Typical chromatogram of tranexamic acid, ethamsylate and drotaverine hydrochloride 


\section{Linearity}

Linearity of the proposed method was determined by constructing calibration graph between the tested concentration level and corresponding peak areas for all three drugs in triplicate. The results show an excellent correlation between peak areas and concentrations level within the tested concentration range of $48-112 \mu \mathrm{g} / \mathrm{ml}$ for drotaverine hydrochloride, $150-350 \mu \mathrm{g} / \mathrm{ml}$ for ethamsylate, and $150-350 \mu \mathrm{g} / \mathrm{ml}$ for tranexamic acid. The correlation coefficients were $>0.999$ for all three drugs, which meet the method validation acceptance criteria, and hence, the method is said to be linear for the drugs (Figs. 3-5).

\section{LOD and LOQ}

The LOD and LOQ for drotaverine hydrochloride were found to be $1 \mu \mathrm{g} / \mathrm{ml}$ and $3 \mu \mathrm{g} / \mathrm{ml}, 0.17 \mu \mathrm{g} / \mathrm{ml}$ and $0.52 \mu \mathrm{g} / \mathrm{ml}$ for ethamsylate, and $0.54 \mu \mathrm{g} / \mathrm{ml}$ and $1.63 \mu \mathrm{g} / \mathrm{ml}$ for tranexamic acid, which indicates that method is sensitive. The results are summarized in Table 2 .

\section{Method precision}

The\% RSD value for six replicates injection of sample and standard as carried out on the same day was found to be $<2 \%$, which indicates that the method is repeatable. The results for method precision are given in Table 3.

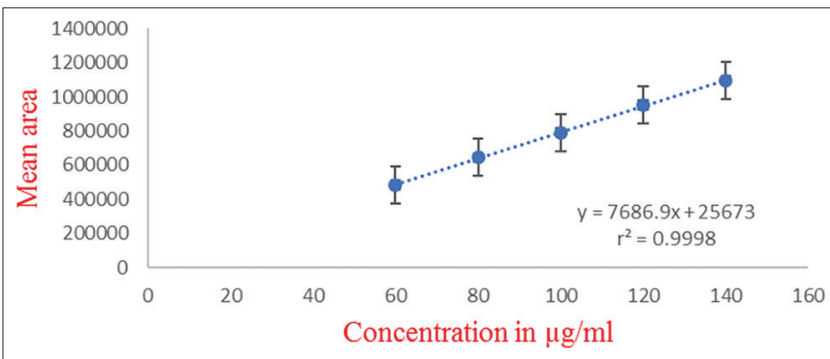

Fig. 3: Graph representing calibration curve of drotaverine hydrochloride. Error bars represent standard deviation of the mean ( \pm standard deviation)

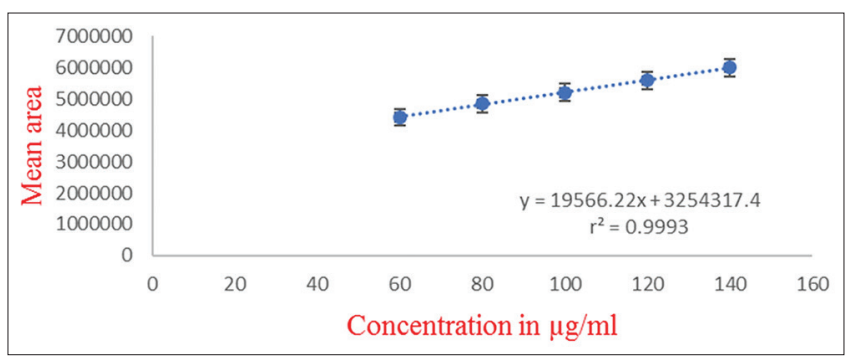

Fig. 4: Graph representing calibration curve of ethamsylate. Error bars represent standard deviation of the mean $( \pm$ standard deviation)

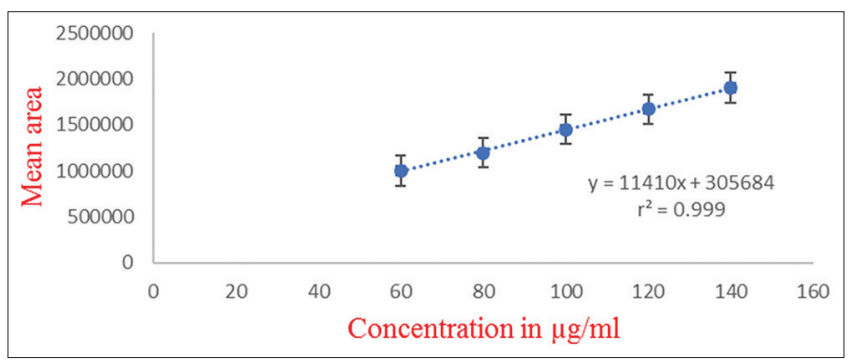

Fig. 5: Graph representing calibration curve of tranexamic acid. Error bars represent standard deviation of the mean $( \pm$ standard deviation)

\section{System precision}

System precision was determined by measuring the peak area of six replicate injections of standard solution. The value of \% RSD was found to be $<2$, which ensure the analytical system is working properly. The results of system precision are tabulated in Table 4.

\section{Accuracy}

The accuracy of this method was determined by calculating percent recovery of drotaverine hydrochloride, ethamsylate, and tranexamic acid in formulation at three different levels $(80-120 \%)$. The \% recovery obtained was found to be in the range of 99.22-99.88 for drotaverine hydrochloride, 99.66-99.7 for ethamsylate, and 99.35-100 for tranexamic acid. The accepted limits of mean recovery are $98-102 \%$ and all observed data were within the required range, which indicate good recovery values, affirming the accuracy of the method developed. The results are summarized in Table 5.

\section{Robustness}

The method was found to be robust when subjected to minor changes in the chromatographic condition such as oven temperature $\left( \pm 1^{\circ} \mathrm{C}\right)$, mobile phase flow rate $( \pm 0.2 \mathrm{ml} / \mathrm{min})$, and wavelength $\mathrm{nm}( \pm 1 \mathrm{~nm})$. It was observed that there was no marked change in analytical method which indicates good reliability during normal usage. The results are shown in Table 6.

\section{Force degradation studies}

Force degradation of drotaverine hydrochloride, ethamsylate, and tranexamic acid under the conditions of hydrolysis (acidic, basic), oxidation, photolysis, and thermal was carried out.

Under acidic conditions ( $0.1 \mathrm{~N}$ hydrochloride for $3 \mathrm{~h}$ ), it was found that $1.74 \%$ of drotaverine hydrochloride, $1.7 \%$ of ethamsylate, and $1.02 \%$ of tranexamic acid content were degraded.

Under basic condition ( $0.1 \mathrm{~N}$ sodium hydroxide for $3 \mathrm{~h}$ ), it was found that $1.02 \%$ of drotaverine hydrochloride, $1.47 \%$ of ethamsylate, and $0.93 \%$ of tranexamic acid content were degraded.

The drug sample when subjected to oxidation (5\% of hydrogen peroxide), it was found that $1.42 \%$ of drotaverine hydrochloride, $1.12 \%$ of ethamsylate, and $1.5 \%$ of tranexamic acid content were degraded.

Under thermal condition (at $100^{\circ} \mathrm{C}$ for $30 \mathrm{~min}$ ), it was found that $1 \%$ of drotaverine hydrochloride, $1.22 \%$ of ethamsylate, and $1.22 \%$ of tranexamic acid content were degraded.

The drug sampled when exposed to UV light for $12 \mathrm{~h}$, it was found that $0.06 \%$ of drotaverine hydrochloride, $0.71 \%$ of ethamsylate, and $0.64 \%$ of tranexamic acid content were degraded.

The drug sample when placed in humidity chamber $\left(25^{\circ} \mathrm{C} \pm 2^{\circ} \mathrm{C} / 60 \%\right.$ $\mathrm{RH} \pm 5 \% \mathrm{RH}$ ), it was found that $1.88 \%$ of drotaverine hydrochloride, $1.03 \%$ of ethamsylate, and $1.88 \%$ of tranexamic acid content were degraded.

As there was no interference observed due to excipients or other component present in pharmaceutical dosage form or degrading products, hence, can be concluded that the developed method is stability indicating method for simultaneous estimation of drotaverine hydrochloride, ethamsylate, and tranexamic acid in pharmaceutical dosage form. The results for force degradation studies are shown in Table 7.

\section{CONCLUSION}

A novel RP-HPLC method was developed for simultaneous estimation of drotaverine hydrochloride, ethamsylate, and tranexamic acid in pharmaceutical dosage form. This newly developed method offers an advantage of being simple, rapid, and accurate and has a shorter chromatographic time. The developed method was validated as per 
Table 1: Results of system suitability studies

\begin{tabular}{|c|c|c|c|}
\hline Parameters $(n=6)$ & Drotaverine hydrochloride & Ethamsylate & Tranexamic acid \\
\hline Number of theoretical plates & 5408 & 6561 & 32908 \\
\hline Tailing factor & 1.16 & 1.25 & 1.84 \\
\hline Peak area & 802571 & 5237256 & 1487598 \\
\hline Retention time (min) & 5.0 & 4.0 & 3.6 \\
\hline
\end{tabular}

Table 2: LOD and LOQ value calculated from the calibration curve

\begin{tabular}{llll}
\hline Parameters & Drotaverine hydrochloride $(\mu \mathrm{g} / \mathrm{ml})$ & Ethamsylate $(\boldsymbol{\mu g} / \mathbf{m l})$ & Tranexamic acid $(\boldsymbol{\mu g} / \mathbf{m l})$ \\
\hline LOD & 3 & 0.17 & 0.54 \\
LOQ & 1 & 0.52 & 1.63 \\
\hline
\end{tabular}

LOD: Limit of detection LOQ: Limit of quantitation

Table 3: Method precision data for drotaverine hydrochloride, ethamsylate, and tranexamic acid in tablet

\begin{tabular}{llll}
\hline Replicates (n=6) & $\begin{array}{l}\text { \% Assay of drotaverine } \\
\text { hydrochloride }\end{array}$ & \% Assay of ethamsylate \\
\hline 1 & 98.07 & 98.6 & 100.07 \\
2 & 98.89 & 99.14 & 98.83 \\
3 & 98.94 & 99.94 & 99.3 \\
4 & 98.34 & 99.41 & 100.11 \\
5 & 98.08 & 99.99 & 98.24 \\
6 & 98.68 & $99.53 \pm 0.5396$ & 98 \\
Mean \pm SD & $98.68 \pm 0.3572$ & 0.22032 & $99.08 \pm 0.8566$ \\
\pm SEM & 0.14584 & 0.54 & 0.352951 \\
\hline RSD & 0.36 & 0.86 \\
\hline
\end{tabular}

n: Number of injections, SD: Standard deviation, SEM: Standard error of mean, \% RSD: Percent relative standard deviation

Table 4: System precision data for drotaverine hydrochloride, ethamsylate, and tranexamic acid

\begin{tabular}{llll}
\hline Replicates (n=6) & Drotaverine hydrochloride (area) & Ethamsylate (area) & Tranexamic acid (area) \\
\hline 1 & 793320 & 5287608 & 1452539 \\
2 & 793124 & 5266508 & 1436249 \\
3 & 792831 & 5198406 & 1451425 \\
4 & 793863 & 5263296 & 1453261 \\
5 & 794823 & 5123486 & 1496321 \\
6 & 792336 & 5263289 & 1436281 \\
Mean \pm SD & $790049.5 \pm 5308.52$ & $5233765.5 \pm 56460.36$ \\
\pm SEM & 2167.19 & 23049.847 & $1454346 \pm 20119.31$ \\
\%RSD & 0.6 & 1.0 & 8213.67 \\
\hline
\end{tabular}

n: Number of injections, SD: Standard deviation, SEM: Standard error of mean, \% RSD: Percent relative standard deviation

Table 5: Recovery data for drotaverine hydrochloride, ethamsylate, and tranexamic acid

\begin{tabular}{|c|c|c|c|c|c|}
\hline Drug & $\begin{array}{l}\text { Level of } \\
\text { recovery }(\%)\end{array}$ & $\begin{array}{l}\text { Sample amount } \\
(\mu \mathrm{g} / \mathrm{ml})\end{array}$ & Standard amount $(\mu \mathrm{g} / \mathrm{ml})$ & Total amount $(\mu \mathrm{g} / \mathrm{ml})$ & $\%$ Mean recovery $(n=3)$ \\
\hline Drotaverine & 80 & 40 & 32 & 72 & 99.88 \\
\hline \multirow{2}{*}{ hydrochloride } & 100 & 40 & 40 & 80 & 99.69 \\
\hline & 120 & 40 & 48 & 88 & 99.22 \\
\hline \multirow[t]{2}{*}{ Ethamsylate } & 80 & 125 & 100 & 225 & 98.77 \\
\hline & 100 & 125 & 125 & 250 & 100.4 \\
\hline Tranexamic & 80 & 125 & 100 & 225 & 100 \\
\hline \multirow[t]{2}{*}{ Acid } & 100 & 125 & 125 & 250 & 99.78 \\
\hline & 120 & 125 & 150 & 275 & 99.35 \\
\hline
\end{tabular}

Table 6: Robustness evaluation of method

\begin{tabular}{|c|c|c|c|c|}
\hline Chromatographic factors & Variations & $\begin{array}{l}\text { \% Assay of drotaverine } \\
\text { hydrochloride }\end{array}$ & $\begin{array}{l}\% \text { Assay of } \\
\text { ethamsylate }\end{array}$ & $\begin{array}{l}\% \text { Assay of } \\
\text { tranexamic acid }\end{array}$ \\
\hline Flow rate $(\mathrm{ml} / \mathrm{min})$ & 0.8 & 99.31 & 99.46 & 99.11 \\
\hline \multirow[t]{2}{*}{ Oven temperature $\left({ }^{\circ} \mathrm{C}\right)$} & 24 & 99.28 & 99.66 & 98.93 \\
\hline & 26 & 99.67 & 99.91 & 99.38 \\
\hline \multirow[t]{2}{*}{ Wavelength (nm) } & 219 & 99.86 & 99.07 & 99.17 \\
\hline & 221 & 99.27 & 99.76 & 99.38 \\
\hline
\end{tabular}


Table 7: Force degradation studies of drotaverine hydrochloride, ethamsylate, and tranexamic acid

\begin{tabular}{|c|c|c|c|c|c|c|}
\hline \multirow[t]{2}{*}{ Stress conditions } & \multicolumn{2}{|c|}{ Drotaverine hydrochloride } & \multicolumn{2}{|c|}{ Ethamsylate } & \multicolumn{2}{|c|}{ Tranexamic acid } \\
\hline & \% Assay & \% Difference & \% Assay & \% Difference & \% Assay & $\%$ Difference \\
\hline Untreated & 9.95 & NA & 99.96 & NA & 99.91 & NA \\
\hline Basic & 98.94 & 1.01 & 98.49 & 1.47 & 98.98 & 0.93 \\
\hline Oxidation & 98.53 & 1.42 & 98.84 & 1.12 & 98.41 & 1.5 \\
\hline Thermal & 98.95 & 1 & 98.98 & 0.98 & 98.69 & 1.22 \\
\hline Photolysis & 98.89 & 0.06 & 99.25 & 0.71 & 99.27 & 0.64 \\
\hline Humidity & 98.07 & 1.88 & 98.93 & 1.03 & 98.03 & 1.88 \\
\hline
\end{tabular}

ICH guidelines and the results obtained were within the acceptance limits. Percent recovery and estimated concentration of active ingredient in pharmaceutical formulation showed that amount of drug present is consistent with the label claim. Hence, the proposed method was found to be satisfactory and can be applied for routine analysis of drotaverine hydrochloride, ethamsylate, and tranexamic acid in pharmaceutical dosage form. This method can be utilized conveniently and easily applied in routine qualitative and quantitative analysis, quality control department and in laboratories.

\section{ACKNOWLEDGMENT}

The authors express their sincere thanks to Principal Dr. (Mrs.) Sudha Rathod, Oriental College of Pharmacy, Sanpada, Navi Mumbai, for providing the necessary facilities to carry out the research work.

\section{CONFLICTS OF INTERESTS}

All authors declare no conflicts of interests.

\section{FINANCIAL SUPPORT AND SPONSORSHIP}

Nil.

\section{REFERENCES}

1. Budawari S. The Merck Index. $13^{\text {th }}$ ed. Whitehouse Station, N.J: Merck and Co Inc.; 2003. p. 609, 9640

2. Elks J, Ganellin CR. The Dictionary of Drugs: Chemical Data, Structures and Bibliographies. $1^{\text {st }}$ ed. London; Royal; 1990. p. 472.
3. Merck and Company. The Merck Index-An Encyclopaedia of Chemicals, Drugs and Biologicals. $13^{\text {th }}$ ed. USA: Merck and Company; 1989. p. 3757, 9648 .

4. Martindale, The extra pharmacopoeia, The complete drug reference. $34^{\text {th }}$ edn. Pharmaceutical press, London; Royal; 2005. p. 749, 760.

5. Sethna NF, Zurakowski D, Brustowicz RM, Bacsik J, Sullivan LJ, Shapiro F, et al. Tranexamic acid reduces intraoperative blood loss in pediatric patients undergoing scoliosis surgery. Anesthesiology 2005; 102:727-32.

6. Her Majesty's Stationary Office. British Pharmacopeia. Vol. I, II. London: Her Majesty's Stationary Office; 2004. p.758, 1960.

7. Jameelunnisa B, Abdul R. Spectrophotometric determination of drotaverine in tablets. Asian J Chem 2008;20:4173-84.

8. Jyotesh J, Riddhish P, Divyesh V, Renu C, Shailesh S. Dual wavelength spectrophotometric method for simultaneous estimation of drotaverine hydrochlorideand aceclofenac in their combined tablet dosage form. Int J Pharm Pharm Sci 2010;4:76-9.

9. Roshan I, Kaushik KV, Diptish KN. Spectrophotometric methods for simultaneous estimation of ethamsylate and tranexamic acid from combined tablet dosage form. Int J Chemtech Res 2010;2:74-8.

10. Reddy NK, Potawale SE, Gabhe SY, Mahadik KR. HPTLC double development and validation of mefenamic acid and tranexamic acid in combined tablet dosage form. Pharm Sinica 2013;4:16-21.

11. Suganthi A, Thengungal KR. Stability indicating hplc method for simultaneous determination of drotaverine and aceclofenac. Int J Pharm Pharm Sci 2011;3:245-50.

12. Srinivasa RA, Pavankumar KL, Satyanarayana P, Subrahmanya S. Simultaneous estimation of mefenamic acid, ethamsylate and tranexamic acid in bulk and pharmaceutical formulations by RP-HPLC method. Am J Pharm Tech Res 2015;5:402-14.

13. ICH. Stability Testing of New Drug Substances and Products (Q1AR2). Geneva: International Conference on Harmonization, IFPMA; 2003. 